\title{
A comparison of ampicillin and amoxycillin in acute on chronic bronchitis
}

\author{
G ANDERSON, A G JARIWALLA,* AND J SAOUR
}

From St Woolos Hospital, Newport, Gwent, UK

\begin{abstract}
Twenty-five patients with an acute exacerbation of chronic bronchitis completed a double-blind trial of amoxycillin $1.5 \mathrm{~g} \mathrm{v}$ ampicillin $4 \mathrm{~g}$ daily. After treatment for one week there was no difference between the treatments in the rates of achieving mucoid sputum, reduction in sputum volume, improvement in peak expiratory flow rate, or duration of hospital stay. In the doses studied ampicillin and amoxycillin are effective drugs of about equal cost.
\end{abstract}

Amoxycillin is a semisynthetic penicillin. In acute on chronic bronchitis it is claimed to be more effective than ampicillin because gastrointestinal absorption is better, it is superior in experimental infections (Acred et al, 1970), and unlike ampicillin it gives high intrabronchial antibiotic levels when the sputum is no longer purulent. The use of amoxycillin has been criticised on grounds of cost but there has been no direct comparison of the two drugs. We report a double-blind trial of amoxycillin and ampicillin in acute exacerbations of chronic bronchitis.

\section{Methods}

Thirty-one patients were studied. All had chronic bronchitis (MRC definition) and had been admitted to hospital with an acute exacerbation. On entry an envelope was opened containing a randomly selected seven-day supply of amoxycillin or ampicillin. Treatment was given as amoxycillin $1.5 \mathrm{~g}$ daily (500 mg thrice daily) or ampicillin $4 \mathrm{~g}$ daily ( $1 \mathrm{~g}$ four times daily). Tablets were made up as identical preparations, and patients received one of the two regimens shown in table 1 . Table 2 shows the characteristics of the two groups of patients completing the trial. Patients were seen by an investigator before entering the trial and subsequently at daily intervals for seven days.

On admission patients were graded as very ill, moderately ill, or slightly ill and at seven days as better, unchanged, or worse. Sputum was examined daily and graded as mucoid, slightly purulent, moderately purulent, and grossly purulent. Sputum volume was measured daily. Drug-induced side effects were recorded. Sputum specimens were taken on admission and cultured within 12 hours, being refrigerated meanwhile. The technique of examination was that described

Table 1 Drug dosage schedule

\begin{tabular}{|c|c|c|}
\hline Time & Amoxycillin group & Ampicillin group \\
\hline 0700 & $\begin{array}{l}1-500 \mathrm{mg} \text { amoxycillin } \\
+1 \text { placebo tablet }\end{array}$ & $\begin{array}{l}2-500 \mathrm{mg} \text { ampicillin } \\
\text { tablets }\end{array}$ \\
\hline 1300 & 2 placebo tablets & $\begin{array}{l}2-500 \mathrm{mg} \text { ampicillin } \\
\text { tablets }\end{array}$ \\
\hline 1500 & $\begin{array}{l}1-500 \mathrm{mg} \text { amoxycillin } \\
+1 \text { placebo tablet }\end{array}$ & 2 placebo tablets \\
\hline 1900 & 2 placebo tablets & $\begin{array}{l}2-500 \mathrm{mg} \text { ampicillin } \\
\text { tablets }\end{array}$ \\
\hline 2300 & $\begin{array}{l}1-500 \mathrm{mg} \text { amoxycillin } \\
+1 \text { placebo tablet }\end{array}$ & $\begin{array}{l}2-500 \mathrm{mg} \text { ampicillin } \\
\text { tablets }\end{array}$ \\
\hline
\end{tabular}

Table 2 Details of 25 patients who completed study

\begin{tabular}{|c|c|c|}
\hline & Ampicillin group & Amoxycillin group \\
\hline No of patients & 11 & 14 \\
\hline Men & 9 & 11 \\
\hline $\begin{array}{l}\text { Median age (years } \\
\text { and range) }\end{array}$ & $\begin{array}{l}66 \\
(38-86)\end{array}$ & $\begin{array}{l}66 \\
(21-74)\end{array}$ \\
\hline $\begin{array}{l}\text { Clinical grading: } \\
\text { Slightly ill } \\
\text { Moderately ill } \\
\text { Severely ill }\end{array}$ & $\begin{array}{l}1 \\
9 \\
1\end{array}$ & $\begin{array}{r}2 \\
11 \\
1\end{array}$ \\
\hline $\begin{array}{l}\text { Coexisting carcinoma } \\
\text { lung }\end{array}$ & 2 & 0 \\
\hline Cor pulmonale & 6 & 6 \\
\hline $\begin{array}{l}\text { Previous antibiotic } \\
\text { treatment }\end{array}$ & $\stackrel{1}{\text { (cephaloridine) }}$ & $\begin{array}{l}2 \\
\text { (tetracycline } \\
\text { co-trimoxazole) }\end{array}$ \\
\hline
\end{tabular}


by Pines et al (1977). Peak expiratory flow rate (PEFR) was recorded daily for seven days.

Patients were excluded if they were known to be allergic to penicillins or cephalosporins or if they had received amoxycillin or ampicillin within one week of hospital admission. Prior administration of other antibiotics did not exclude them. Withdrawal from the trial was allowed if the sputum became increasingly purulent or if purulence failed to improve after treatment for three days. They could then receive other antibiotics and were classed as treatment failures.

\section{Results}

\section{PATIENT DETAILS}

Thirty-one patients entered the trial, 14 receiving ampicillin and 17 amoxycillin. Three patients in each treatment group were withdrawn leaving 25 (11 ampicillin, 14 amoxycillin) eligible for assessment. The reasons for withdrawal were, in the ampicillin group; one death on day three, one had a stroke and could not take tablets, and one was found to have stridor due to lung cancer; and in the amoxycillin group: one took his own discharge, one treatment failure, and in one further investigations showed asthma.

The results of pretreatment sputum bacteriological examination are shown in table 3. Pathogenic bacteria were grown from five patients receiving ampicillin and from four having amoxycillin. All organisms were sensitive to ampicillin.

\section{DAILY ASSESSMENT}

Sputum purulence-In all patients in both groups (except the patient who died) the sputum

Table 3 Results of pretreatment sputum bacteriological examination

\begin{tabular}{lll}
\hline Organism & $\begin{array}{l}\text { Ampicillin } \\
\text { group }\end{array}$ & $\begin{array}{l}\text { Amoxycillin } \\
\text { group }\end{array}$ \\
\hline Haemophilus influenzae & 2 & 3 \\
Streptococcus pneumoniae & 2 & 1 \\
Staphylococcus aureus & 1 & 0 \\
Total with organisms & $5(45 \%)$ & $4(28 \%)$ \\
\hline
\end{tabular}

became and remained mucoid during the seven days of treatment. The median time was day four for ampicillin and day five for amoxycillin. The two groups were not significantly different in this respect.

Sputum volume-Table 4 gives the median and range of sputum volume for each day. There is a similar reduction with both drugs over the treatment period.

Peak expiratory flow rate-The median daily improvement in PEFR for ampicillin was $351 / \mathrm{min}$ and for amoxycillin $40 \mathrm{l} / \mathrm{min}$. The median increases on day seven for both drugs were not statistically different.

Post-treatment assessments-All patients were assessed as better after their course of treatment with the exception of the patient receiving amoxycillin who was classified as a treatment failure and the patient receiving ampicillin who died on day three. The median durations of hospital stay were ampicillin 10 days (range 7-18) and amoxycillin nine days (range 7-71).

Side effects-Side effects were minimal with both drugs. In the ampicillin group one patient had mild diarrhoea and another vomiting and a rash possibly caused by ampicillin. In the amoxycillin group one patient developed an urticarial rash and one had transient vomiting.

\section{Discussion}

Amoxycillin shows better sputum penetration than ampicillin both when the sputum is purulent or mucoid (May and Ingold, 1974). With amoxycillin but not ampicillin sputum levels rise in proportion to the increase in dosage (Ingold, 1975). In addition, in experimental infections amoxycillin produces a quicker bacterial kill than ampicillin (Acred et al, 1970). May and Ingold (1974) stated that "preliminary observations suggest that amoxycillin is likely to supersede ampicillin in the treatment of all infections of the lower respiratory tract caused by sensitive bacterial species." Grant (1976) dissented from this view and noted the greatly increased cost of using amoxycillin and that no direct trial had compared the two drugs.

Table 4 Sputum volume

\begin{tabular}{|c|c|c|c|c|c|c|c|}
\hline & \multicolumn{7}{|c|}{ Daily group medians and ranges $(\mathrm{ml})$} \\
\hline & 1 & 2 & 3 & 4 & 5 & 6 & 7 \\
\hline Ampicillin group & $\begin{array}{l}25 \\
(10-60)\end{array}$ & $\begin{array}{l}20 \\
(10-50)\end{array}$ & $\begin{array}{l}20 \\
(5-50)\end{array}$ & $\begin{array}{l}20 \\
(5-25)\end{array}$ & $\begin{array}{l}10 \\
(5-25)\end{array}$ & $\begin{array}{l}10 \\
(0-30)\end{array}$ & $\begin{array}{l}5 \\
(0-25)\end{array}$ \\
\hline Amoxycillin group & $\begin{array}{l}30 \\
(15-70)\end{array}$ & $\begin{array}{l}20 \\
(10-60)\end{array}$ & $\begin{array}{l}20 \\
(10-30)\end{array}$ & $\begin{array}{l}15 \\
(5-30)\end{array}$ & $\begin{array}{l}10 \\
(5-25)\end{array}$ & $\begin{array}{l}10 \\
(5-20)\end{array}$ & $\begin{array}{l}10 \\
(5-20)\end{array}$ \\
\hline
\end{tabular}


In the present study we have assessed the use of large doses of amoxycillin and ampicillin on sputum purulence and volume, lung function, and clinical state. Both drugs are equally effective, and only one patient (receiving amoxycillin) failed to achieve reversibility of sputum purulence.

One point of interest, however, was rate of clearance of sputum purulence. The results show a slightly faster rate of ampicillin (median day four) than amoxycillin (median day five). The observed proportion of patients in each group whose sputum was first mucoid by day four was $8 / 11(73 \%)$ in the ampicillin group and $5 / 13$ $(38 \%)$ in the amoxycillin group. Although this difference seems large, it is not statistically significant. Assuming that the true population proportions are $73 \%$ and $38 \%$ respectively for ampicillin and amoxycillin, even with a difference as large as this $(35 \%)$, with sample sizes of only 11 and 13 the probability of showing no difference is $58 \%$. With a smaller population difference and the same sample sizes the chance of finding no difference is obviously greater.

Use of both drugs was accompanied by similar improvements in PEFR and all patients were assessed as better after seven days' treatment, while the durations of hospital stay were similar. The incidence of side effects with both drugs was low but similar.

It has been claimed (Pines et al, 1977) that amoxycillin is more effective than other antibiotics in preventing subsequent chest infection in the chronic bronchitic because of its ability to eradicate Haemophilus influenzae from the bronchi. We are not able to refute this claim. $A$ 을 similar study using various low dose regimens is

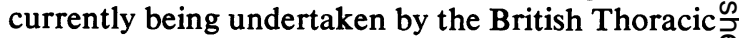
Association. Grant (1976) criticised the use of $\stackrel{\mathbb{Q}}{\mathscr{Q}}$ amoxycillin rather than ampicillin on cost grounds, 串 based on cost per 100 tablets. In the present study $\vec{A}$ the doses used each cost about $£ 5$ for one week's: treatment, amoxycillin being marginally cheaper.

We thank Beecham Pharmaceuticals for supplying $\underset{x}{\vec{x}}$ the drugs and for the statistical analysis.

\section{References}

Acred, P, Hunter, P, Mizen, L, and Rolinson, G N 을 (1970). $\delta$-Amino-p-hydroxybenzylpenicillin, new $\rightarrow$ semisynthetic penicillin, in vitro evaluation. Antimicrobial Agents and Chemotherapy. 10th Interscience Conference, pp 416-422. Bethesda, American Society of Microbiology.

Grant, I W B (1976). Amoxycillin, talampicillin and ampicillin. British Medical Journal, 2, 106.

Ingold, A (1975). Sputum and serum levels of amoxycillin in chronic bronchial infections. British Journal of Diseases of the Chest, 69, 211-216.

May, J R, and Ingold, A (1974). Amoxycillin (BRL 2333). International Symposium, No 326, p 130. Excerpta Medica, Amsterdam.

Pines, A, Nandi, A R, Raafat, $\mathbf{H}$, and Rahman, $M \stackrel{\mathrm{O}}{\mathrm{D}}$ (1977). Amoxycillin and co-trimoxazole in acute purulent exacerbations of chronic bronchitis. Chemotherapy, 23, 58-64.

Requests for reprints to: Dr G Anderson, St Woolos Hospital, Newport, Gwent. 